\title{
The role of vitamin D in Crohn's disease: Literature review
}

\section{Rola witaminy D w chorobie Leśniowskiego-Crohna - przegląd literatury}

\author{
Iga J. Gromny ${ }^{A-D}$ \\ Department and Clinic of Gastroenterology and Hepatology, Wroclaw Medical University, Wrocław, Poland \\ A - research concept and design; $B$ - collection and/or assembly of data; $C$ - data analysis and interpretation; \\ $D$ - writing the article; $E$ - critical revision of the article; $F$ - final approval of article
}

Address for correspondence

Iga J. Gromny

E-mail: igagromny@op.pl

Conflict of interests

None declared

Received on July 13, 2017

Rewieved on August 29, 2017

Accepted on September 16, 2017

\begin{abstract}
Crohn's disease is a form of inflammatory bowel disease which may affect any part of the gastrointestinal tract. The etiology of the disease remains unclear. Genetic, environmental and immunological factors are considered. The deficiency of vitamin D is common among patients with Crohn's disease. Vitamin D, because of its immunomodulatory properties, may influence the development and course of Crohn's disease. Patients with Crohn's disease present some additional risk factors of osteoporosis such as maldigestion and malabsorption, increased loss of nutrients due to chronic diarrhea, pharmacological treatment, as well as past surgical procedures (resection of ileum). Because of the food intolerance, the diet of patients suffering from Crohn's disease may include reduced amounts of calcium and vitamin D, thus, contributing to the increased risk of osteoporosis. As a result of the above-mentioned factors, there is a need for monitoring and proper supplementation of vitamin D in Crohn's disease patients.
\end{abstract}

Key words: Crohn's disease, inflammatory bowel diseases, vitamin D

DOI

10.17219/pzp/77039

Copyright

(c) 2018 by Wroclaw Medical University

This is an article distributed under the terms of the

Creative Commons Attribution Non-Commercial License

(http://creativecommons.org/licenses/by-nc-nd/4.0/) 


\section{Streszczenie}

Choroba Crohna zaliczana jest do nieswoistych chorób zapalnych jelit. Zmiany zapalne w jej przebiegu mogą obejmować wszystkie części przewodu pokarmowego. Etiologia choroby nie jest do końca jasna, wśród jej przyczyn wymienia się czynniki genetyczne, immunologiczne i środowiskowe. U pacjentów, u których zdiagnozowano chorobę Crohna, często stwierdza się niedobory witaminy D. Witamina D, z uwagi na jej immunomodulujące właściwość, może wpływać na rozwój oraz przebieg choroby Crohna. U osób z rozpoznaniem choroby Crohna występują pewne dodatkowe czynniki ryzyka wystąpienia osteoporozy. Możemy do nich zaliczyć zaburzenia trawienia oraz wchłaniania, utratę składników odżywczych na skutek przewlekłej biegunki, stosowane leki, zabiegi chirurgiczne (między innymi polegające na usunięciu istotnych części jelita cienkiego). Pacjenci z chorobą Leśniowskiego-Crohna nie tolerują niektórych pokarmów, co może wiązać się ze zmniejzzoną zawartością wapnia i witaminy D i tym samym przyczyniać się do zwiększenia ryzyka wystąpienia osteoporozy. Z tego powodu u pacjentów z chorobą Crohna istnieje konieczność monitorowania oraz właściwej suplementacji witaminy D.

Słowa kluczowe: nieswoiste choroby zapalne jelit, choroba Leśniowskiego-Crohna, witamina D

\section{Background}

Crohn's disease (CD) is a form of inflammatory bowel disease (IBD) that may affect any part of the gastrointestinal tract, primarily the ileum and colon. ${ }^{1}$

The etiology of CD remains unclear. Genetic, environmental and immunological factors are considered. ${ }^{2}$

Crohn's disease is most often diagnosed in patient before 30 , however, the second peak occurs at about the age of $50 .{ }^{3}$ In the course of $\mathrm{CD}$, we differentiate both intestinal and extra-intestinal symptoms. As far as intestinal symptoms are concerned, we can mention abdominal pain, diarrhea, nausea, vomiting and weight loss.

The extra-intestinal manifestations of $\mathrm{CD}$ are the following: arthritis, erythema nodosum, pyoderma gangrenosum, uveitis, primary sclerosing cholangitis and osteoporosis. ${ }^{4}$

Since the early 1980s, vitamin D deficiency has been regarded as a risk factor of $\mathrm{CD} .{ }^{5}$ It is considered that vitamin D insufficiency affects about $35-100 \%$ of patients with $\mathrm{CD}{ }^{6}$

Vitamin D may suppress microbial invasion into the gut epithelium. It is important because of the pathomechanism of $C D$ in which we observe a dysfunction of the immune defense barrier of the intestines. Vitamin D inhibits the transcription of pro-inflammatory cytokines increased in CD patients. ${ }^{7,8}$ The level of vitamin D may affect the course and activity of the disease and impact quality of life and the frequency of hospitalizations.

\section{Vitamin D}

Vitamin D, also known as calciferol, belongs to the group of fat-soluble seco-sterols. There are two main forms of vitamin $\mathrm{D}$ - vitamin $\mathrm{D}_{2}$ (ergocalciferol) and vitamin $\mathrm{D}_{3}$ (cholecalciferol). ${ }^{9}$ Dietary sources of vitamin $\mathrm{D}_{2}$ involve irradiated yeast, plants and fungi. Vitamin $\mathrm{D}_{3}$ is produced from 7-dehydrocholesterol in the epidermal layer of the skin by exposure to ultraviolet $B$ radiation (spectrum 290-315) or can be obtained from diet (fish, meat, offal, egg or dairy). ${ }^{10}$
The $D_{2}$ and $D_{3}$ forms differ in their structure but the metabolic pathway of both vitamins is the same. However, there is no evidence that both forms of vitamin D have the same biological activity. But, based on the current data, it can be assumed that vitamin $\mathrm{D}$ has a greater biological potential. ${ }^{11}$

The best measure of an individual's vitamin D status is serum 25-hydroxyvitamin D. It reflects both sunlight exposure and dietary vitamin $\mathrm{D}$ intake.

The normal level of vitamin $\mathrm{D}$ in serum is approx. $30 \mathrm{ng} / \mathrm{mL}$. The level between 20 and $30 \mathrm{ng} / \mathrm{mL}$ is considered to be insufficient and below $20 \mathrm{ng} / \mathrm{mL}$ is recognized as deficient. ${ }^{12}$

Firstly, vitamin D is metabolized in the liver to 25 hydroxyvitamin $\mathrm{D}(25(\mathrm{OH}) \mathrm{D}$-calcidiol) by the 25 -hydroxylase. The level of 25(OH)D is used to assess vitamin D status. 25 hydroxyvitamin $\mathrm{D}$ is the major circulating form of vitamin $\mathrm{D}$, bounded to a plasma protein known as vitamin D binding protein which also transports vitamin D and calcitriol. ${ }^{13}$

In the kidney, the $1 \alpha$-hydroxylase converts $25(\mathrm{OH}) \mathrm{D}$ to the biologically active form 1,25-dihydroxyvitamin $\mathrm{D}$ $\left(\left[1,25(\mathrm{OH})_{2} \mathrm{D}\right]\right.$-calcitriol). $1,25(\mathrm{OH})_{2} \mathrm{D}$ increases calcium absorption in the duodenum and stimulates differentiation and activation of osteoblasts and osteoclasts in bones. ${ }^{14}$

Vitamin D receptor (VDR) is present in almost all tissues and cells of the human body. The role of VDR is heterogeneous. For instance, it inhibits cellular proliferation, angiogenesis and renin production, induces terminal differentiation and stimulates insulin production. ${ }^{15}$

A decreased level of vitamin $D$ is frequent among newly-diagnosed IBD patients. This may indicate that vitamin D deficiency is related to the increased risk of IBD.

Nerih et al., in a cohort study, showed that women living in southern latitudes had lower risk of developing $\mathrm{CD}$ (hazard ratio [HR] 0.48, 95\% confidence interval [CI] $0.3-0.7$ ) and colitis ulcerosa [HR 0.62, 95\% CI 0.4-0.9] than those living in northern latitudes. ${ }^{16}$ This suggests that there is a possible role of vitamin D in the pathogenesis of CD.

The absorption of vitamin $\mathrm{D}$ occurs in the proximal small intestine, mainly in the jejunum. 
Fat malabsorption and inflammation of the small intestine may be the main cause of vitamin $\mathrm{D}$ deficiency in $C D$ as well as of the removal of large sections of the ileum or the jejunum.

Farraye et al. noticed that even in quiescent disease, the capability to absorb vitamin $\mathrm{D}$ is decreased on average by $30 \%$ compared to healthy controls after supplementation with $1250 \mu \mathrm{g}(50000 \mathrm{IU})$ vitamin $\mathrm{D}_{2} \cdot{ }^{17}$

Some drugs may affect the absorption of vitamin D. For instance, cholestyramine, which is used to treat diarrhea after bowel resection, can reduce vitamin D absorption by decreasing bile acid production.

Drugs used in CD can also influence the level of serum vitamin $\mathrm{D}$ indirectly. Treatment with azathioprine or adalimumab, can increase the risk of skin cancer. For these reasons, such patients are made aware of the danger of sun exposure. Therefore, the vitamin D synthesis from sun exposure may be reduced. ${ }^{18}$

\section{Osteoporosis in the course of Crohn's disease}

According to the World Health Organization (WHO), osteoporosis is the reduction in bone mineral density (BMD) by 2.5 or more standard deviations below that of the mean peak BMD of young adults measured by dualenergy x-ray absorptiometry (DEXA). ${ }^{19}$

Low BMD is a common extra-intestinal manifestation in CD. It is estimated that osteoporosis affects approx. $40 \%$ of patients with CD. ${ }^{20}$ There are some additional risk factors of low BMD among patients with $\mathrm{CD}$, for instance, chronic inflammation, corticosteroid treatment, extensive small-bowel disease or resection and nutritional deficiencies. ${ }^{21}$ Screening recommendations for $C D$ patients are the same as for the general population, which are based on risk factors such as ongoing corticosteroid treatment, corticosteroid use more than 3 months, postmenopausal status, age and previous low-trauma fracture. ${ }^{22,23}$ Corticosteroids decrease BMD by the suppression of circulating estrogen, which inhibits interleukin-6 (IL-6). This cytokine has the ability to stimulate the activation of osteoclasts. ${ }^{24}$ What is more, in men, steroids decrease the level of testosterone in the blood, which results in a similar effect on bones. ${ }^{25}$ Steroids inhibit osteoblast differentiation, synthetic ability and calcium absorption. On the other hand, other pharmacological treatments such as anti-TNF therapy improves BMD. ${ }^{26}$ It protects bones against osteoclasts by reducing $\alpha-T N F$, which may activate the mechanisms of bone destruction.

Most of the studies suggest that lower BMD is more frequent in CD than in ulcerative colitis (UC). Moreover, there is an increased risk of low energy fractures in female patients with $C D$, but not in male patients with $C D$ or in patients with UC. ${ }^{27}$
The inflammation on its own may accelerate the risk of lowered bone density through pro-inflammatory cytokines such as tumor necrosis factor- $\alpha$, interleukin-1 $\beta$ or IL-6 TNF-related cytokines (tumor necrosis factor) like the receptor activator of nuclear factor kappa B (RANK), its ligand RANKL and osteoprotegerin.

Vitamin D regulates bone metabolism both directly and indirectly. It acts on osteoblasts, osteocytes and osteoclasts and controls the transcription of genes and the differentiation and mineralization of osteoblasts. It also has an impact on the production of type-I collagen, osteocalcin, osteopontin and bone sialoprotein (BSP1).

Calciferol stimulates osteocytes to produce fibroblast growth factor 23, which manages the hydroxylation of $1,25(\mathrm{OH})_{2} \mathrm{D}_{3}$ in kidneys, inhibits the reabsorption of phosphates and decreases the production of para-thormone.

Vitamin D activates preosteoblasts to release the macrophage-colony stimulating factor (M-CSF), which activates the proliferation of prosteoclasts and inhibits their apoptosis. On the membrane of prosteoclasts, there is a receptor activator of nuclear factor kappa-B (RANK). Prosteoblasts release Receptor activator of nuclear factor kappa-B ligand (RANKL), which binds with RANK. This results in the activation of osteoclasts.

Osteoblasts produce osteoprotegerin, which may bind with RANKL and inhibits its binding with RANK, stopping osteoclast differentiation. Vitamin D increases in the expression of RANKL in osteoblasts and inhibits the expression of OPG, which results in stimulating osteoclastogenesis. ${ }^{28}$

There are a few studies on the relationship between serum 25(OH) D and bone mineral density in patients with CD whose findings are contradictory. Some researchers suggest that there is a relationship between vitamin D level and bone mineral density in adults while others do not find such a correlation. ${ }^{29,30}$

Krela-Kaźmierczak et al. studied the association between the serum levels of interleukins (IL-13, IL-4, IL-17, IL-1 $\beta$ ), osteoprotegerin and s-RANKL proteins in patients with $C D$ and decreased BMD. The results of their study showed that IL-13, IL-1 $\beta$, and IL-4 seem to be connected with the pathology of low BMD in CD. Furthermore, modulating osteoprotegerin by Il-13 may decrease BMD. ${ }^{31}$

\section{Influence of vitamin D level on disease activity, quality of life and hospitalization rate}

Studies suggest that vitamin D levels inversely correlate with disease activity in patients with CD.

Sadeghian et al. found that patients with $C D$ had lower serum $25(\mathrm{OH}) \mathrm{D}$ level in comparison to healthy controls. What is more, there was an inverse correlation between serum $25(\mathrm{OH}) \mathrm{D}$ concentrations and severity of CD. ${ }^{32}$ 
In a cross-sectional study of $182 \mathrm{CD}$ patients and 62 healthy controls, serum 25-OH vitamin D was measured. By stratified analysis, 25-OH vitamin D levels were compare to Crohn's disease activity index and C-reactive protein. Serum 25-OH vitamin D was inversely associated with disease activity. Patients who took oral vitamin D supplementation had lower Crohn's disease activity index and C-reactive protein than non-users. ${ }^{33}$

In another cross-sectional study, the relationship between serum vitamin D level and both disease activity and quality of life among patients with IBD was examined. Quality of life was assessed by the Short Inflammatory Bowel Disease Questionnaire (SIBDQ). Vitamin D deficiency was independently correlated with lower quality of life and greater disease activity in IBD. ${ }^{34}$

Serum vitamin D levels may also affect the frequency of hospitalization of patients with $\mathrm{CD}$. In a retrospective cohort study, an association between vitamin $\mathrm{D}$ level and hospitalization rate in Crohn's disease patients was assessed. The study showed that CD patients with a low vitamin D level were almost twice as likely to be admitted to a hospital than those with a normal vitamin D level. Higher mean vitamin D level was associated with a $3 \%$ lower likelihood of admission with every unit $(\mathrm{ng} / \mathrm{mL})$ rise in mean vitamin D level. ${ }^{35}$ In conclusion, the above-mentioned studies have shown that a decreased level of vitamin D is related to higher severity of the disease and the frequency of hospitalizations as well as lower life quality.

\section{Supplementation of vitamin D}

In accordance with the first European Crohn's and Colitis Organisation (ECCO) consensus guideline, supplementation of vitamin $\mathrm{D}$ and calcium should be considered in patients with low BMD and/or with additional risk factors. ${ }^{36}$

FRAX (fracture risk calculator) can be a useful tool which helps to identify people who may be at risk of developing osteoporosis. It is a diagnostic tool used to evaluate the probability of bone fracture in the next 10 years. ${ }^{37}$ However, until now, FRAX has not been validated in IBD.

The recommended dosage of vitamin D is $1000 \mathrm{IU}$ daily. A higher dose is required if deficiency of vitamin D is recognized. Additional substitution of calcium is recommended only when there is not enough calcium in the diet. Studies show that the daily supplementation of calcium (500-1000 mg) and vitamin D (800-1000 mg) increases BMD in IBD patients. It is suggested to receive vitamin $\mathrm{D}$ and calcium preparations during corticosteroid treatment. ${ }^{38}$

\section{Summary}

Vitamin D plays an important role in the maintenance of a normal mineralized bone structure. It af- fects both the pathogenesis and the course of Crohn's disease.

In the light of the above-mentioned studies, it is necessary to control the serum level of vitamin D and its appropriate oral supplementation.

\section{References}

1. Hendrickson BA, Gokhale R, Cho JH. Clinical aspects and pathophysiology of inflammatory bowel disease. Clin Microbiol Rev. 2002;15(1):79-94. doi: 10.1128/cmr.15.1.79-94.2002.

2. Baumgart DC, Sandborn WJ. Crohn's disease. Lancet. 2012;380(9853):1590-1605. doi:10.1016/S0140-6736(12)60026-9.

3. Sandler RS, Golden AL. Epidemiology of Crohn's disease. J Clin Gastroenterol. 1986;8(2):160-165.

4. Levine JS, Burakoff R. Extraintestinal manifestations of inflammatory bowel disease. Gastroenterol Hepatol (N Y). 2011;7(4):235-241.

5. Ardesia M, Ferlazzo G, Fries W. Vitamin D and inflammatory bowel disease. Biomed Res Int. 2015;2015:470805. doi: 10.1155/2015/470805.

6. Nic Suibhne T, Cox G, Healy M, O'Morain C, O'Sullivan M. Vitamin $D$ deficiency in Crohn's disease: Prevalence, risk factors and supplement use in an outpatient setting. J Crohn's Colitis. 2012;6(2): 182-188. doi: 10.1016/j.crohns.2011.08.002.

7. Pastorelli L, De Salvo C, Mercado JR, Vecchi M, Pizarro TT. Central role of the gut epithelial barrier in the pathogenesis of chronic intestinal inflammation: Lessons learned from animal models and human genetics. Front Immunol. 2013;4:280. doi: 10.3389/ fimmu.2013.00280.

8. Abdo J, Rai V, Agrawal DK. Interplay of immunity and vitamin D: Interactions and implications with current IBD therapy. Curr Med Chem. 2017;24(9):852-867. doi: 10.2174/0929867323666161026124951.

9. Holick MF, MacLaughlin JA, Clark MB, et al. Photosynthesis of previtamin D3 in human skin and the physiologic consequences. Science. 1980;210(4466):203-205.

10. Jäpelt RB, Jakobsen J. Vitamin D in plants: A review of occurrence, analysis, and biosynthesis. Front Plant Sci. 2013;4:136. doi: 10.3389/ fpls.2013.00136.

11. Heaney RP, Recker RR, Grote J, Horst RL, Armas LAG. Vitamin $D_{3}$ is more potent than vitamin $D_{2}$ in humans. J Clin Endocrinol Metab. 2011;96(3):E447-E452. doi: 10.1210/jc.2010-2230.

12. Kennel KA, Drake MT, Hurley DL. Vitamin D deficiency in adults: When to test and how to treat. Mayo Clin Proc. 2010;85(8):752-757; quiz 757-758. doi: 10.4065/mcp.2010.0138.

13. Bikle DD. Vitamin D metabolism, mechanism of action, and clinical applications. Chem Biol. 2014;21(3):319-329. doi: 10.1016/j.chembiol.2013.12.016.

14. Bikle D. Vitamin D: Production, Metabolism, and Mechanisms of Action. MDText.com, Inc.; 2000. http://www.ncbi.nlm.nih.gov/ pubmed/25905172. Accessed August 31, 2017.

15. Campbell FC, Xu H, El-Tanani M, Crowe P, Bingham V. The yin and yang of vitamin $D$ receptor (VDR) signaling in neoplastic progression: Operational networks and tissue-specific growth control. Biochem Pharmacol. 2010;79(1):1-9. doi: 10.1016/j.bcp.2009.09.005.

16. Nerich V, Jantchou P, Boutron-Ruault M-C, et al. Low exposure to sunlight is a risk factor for Crohn's disease. Aliment Pharmacol Ther. 2011;33(8):940-945. doi: 10.1111/j.1365-2036.2011.04601.x.

17. Farraye FA, Nimitphong $H$, Stucchi $A$, et al. Use of a novel vitamin $D$ bioavailability test demonstrates that vitamin $D$ absorption is decreased in patients with quiescent Crohn's disease. Inflamm Bowel Dis. 2011;17(10):2116-2121. doi: 10.1002/ibd.21595.

18. Maddox JS, Soltani K. Risk of nonmelanoma skin cancer with azathioprine use. Inflamm Bowel Dis. 2008;14(10):1425-1431. doi: 10. 1002/ibd.20444.

19. Blake GM, Fogelman I. The role of DXA bone density scans in the diagnosis and treatment of osteoporosis. Postgrad Med J. 2007;83(982):509-517. doi: 10.1136/pgmj.2007.057505.

20. Compston JE, Judd D, Crawley EO, et al. Osteoporosis in patients with inflammatory bowel disease. Gut. 1987;28(4):410-415.

21. Reinshagen M. Osteoporosis in inflammatory bowel disease. J Crohn's Colitis. 2008;2(3):202-207. doi: 10.1016/j.crohns. 2008.01.005. 
22. Compston J, Bowring C, Cooper A, et al. Diagnosis and management of osteoporosis in postmenopausal women and older men in the UK: National Osteoporosis Guideline Group (NOGG) update 2013. Maturitas. 2013;75(4):392-396. doi: 10.1016/j.maturitas.2013.05.013.

23. Nelson HD, Haney EM, Chou R, Dana T, Fu R, Bougatsos C. Screening for Osteoporosis. Agency for Healthcare Research and Quality (US); 2010. http://www.ncbi.nlm.nih.gov/pubmed/20722176. Accessed July 8, 2017.

24. Epstein FH, Manolagas SC, Jilka RL. Bone marrow, cytokines, and bone remodeling - emerging insights into the pathophysiology of osteoporosis. N Engl J Med. 1995;332(5):305-311. doi: 10.1056/ NEJM199502023320506.

25. Schaison G, Durand F, Mowszowicz I. Effect of glucocorticoids on plasma testosterone in men. Acta Endocrinol (Copenh). 1978;89(1):126-131.

26. Bernstein $M$, Irwin S, Greenberg GR. Maintenance infliximab treatment is associated with improved bone mineral density in Crohn's disease. Am J Gastroenterol. 2005;100(9):2031-2035. doi: 10.1111/j.1572-0241.2005.50219.x.

27. Vestergaard P, Krogh K, Rejnmark L, Laurberg S, Mosekilde L. Frac ture risk is increased in Crohn's disease, but not in ulcerative colitis. Gut. 2000;46(2):176-181. doi: 10.1136/gut.46.2.176.

28. Kohli SS, Kohli VS. Role of RANKL-RANK/osteoprotegerin molecular complex in bone remodeling and its immunopathologic implications. Indian J Endocrinol Metab. 2011;15(3):175-181. doi: 10.4103/2230-8210.83401.

29. Shirazi KM, Somi MH, Rezaeifar P, Fattahi I, Khoshbaten M, Ahmadzadeh M. Bone density and bone metabolism in patients with inflammatory bowel disease. Saudi J Gastroenterol. 2012;18(4):241-247. doi: 10.4103/1319-3767.98428.

30. Middleton JP, Bhagavathula AP, Gaye B, et al. Vitamin D status and bone mineral density in African American children with Crohn disease. J Pediatr Gastroenterol Nutr. 2013;57(5):587-93. doi: 10.1097/MPG.0b013e31829e0b89.

31. Krela-Kaźmierczak I, Szymczak A, Łykowska-Szuber L, et al. The importance of vitamin $D$ in the pathology of bone metabolism in inflammatory bowel diseases. Arch Med Sci. 2015;11(5):1028-1032. doi: 10.5114/aoms.2015.54858.

32. Sadeghian M, Saneei P, Siassi F, Esmaillzadeh A. Vitamin D status in relation to Crohn's disease: Meta-analysis of observational studies. Nutrition. 2016;32(5):505-514. doi: 10.1016/j.nut.2015.11.008.

33. Jørgensen SP, Hvas CL, Agnholt J, Christensen LA, Heickendorff $\mathrm{L}$, Dahlerup JF. Active Crohn's disease is associated with low vitamin D levels. J Crohn's Colitis. 2013;7(10):e407-e413. doi: 10.1016/j. crohns.2013.01.012.

34. Castro FD, Magalhães J, Carvalho PB, Moreira MJ, Mota P, Cotter J. Lower levels of vitamin $D$ correlate with clinical disease activity and quality of life in inflammatory bowel disease. Arq Gastroenterol. 2015;52(4):260-265. doi: 10.1590/S0004-28032015000400003.

35. Venkata KVR, Arora SS, Xie FL, Malik TA. Impact of vitamin D on the hospitalization rate of Crohn's disease patients seen at a tertiary care center. World J Gastroenterol. 2017;23(14):2539-2544. doi: 10.3748/wjg.v23.i14.2539.

36. Harbord M, Annese V, Vavricka SR, et al. The first European evidence-based consensus on extra-intestinal manifestations in inflammatory bowel disease. J Crohns Colitis. 2016;10(3):239-254. doi: 10.1093/ecco-jcc/jjv213.

37. Azagra R, Roca G, Encabo G, et al. FRAX ${ }^{\circledR}$ tool, the WHO algorithm to predict osteoporotic fractures: The first analysis of its discriminative and predictive ability in the Spanish FRIDEX cohort. BMC Musculoskelet Disord. 2012;13:204. doi: 10.1186/1471-2474-13-204.

38. Harbord M, Annese V, Vavricka SR, et al. The first European evidence-based Consensus on extra-intestinal manifestations in inflammatory bowel disease. J Crohns Colitis. 2016;10(3):239-254. doi: 10.1093/ecco-jcc/jjv213. 